\title{
Characterization and effect of clarified araçá (Psidium guineenses Sw.) juice on postprandial glycemia in healthy subjects
}

\author{
Caracterização e efeito do suco de araçá (Psidium guineenses Sw.) \\ clarificado na glicemia pós-prandial em indivíduos saudáveis
}

\author{
Diully Mata BALISTEIRO ${ }^{1}$, Marcela Roquim ALEZANDRO ${ }^{1}$, Maria Inés GENOVESE ${ }^{1 \star}$
}

\begin{abstract}
Brazilian native fruits are excellent sources of bioactive compounds of phenolic nature. Some of these compounds are able to inhibit carbohydrate- metabolizing enzymes (in vitro), $\alpha$-amylase and $\alpha$-glucosidase, delaying carbohydrate digestion. This study aimed to evaluate the effect of clarified araçá (Psidium guineenses Sw.) juice on postprandial glycemia in humans after consumption of $25 \mathrm{~g}$ of available carbohydrates (approximately $50 \mathrm{~g}$ of white bread) and characterize the phenolic compounds and in vitro antioxidant capacity of araçá juice and pulp. The results showed that the clarified juice had a positive effect on postprandial glycemia reducing the total amount of glucose absorbed, lengthening the time to reach maximum blood glucose concentration, reducing glucose incremental velocity, and decreasing glucose incremental percentage. Both frozen pulp and clarified juice had high amounts of phenolic compounds, antioxidant capacity, and proanthocyanidins, among which oligomers (monomers to tetramers), pentamers, hexamers, heptamers, octamers, nonamers, decamers, and polymers were detected, and they are probably associated with in vivo effects.
\end{abstract}

Keywords: araçá; postprandial glycemia; diabetes.

\section{Resumo}

Frutas nativas brasileiras são excelentes fontes de compostos bioativos de natureza fenólica. Alguns destes compostos são capazes de inibir in vitro as enzimas do metabolismo de carboidratos, $\alpha$-amilase e $\alpha$-glicosidase, o que retarda o tempo de digestão de carboidratos. Neste trabalho, objetivou-se avaliar o efeito do suco de araçá (Psidium guineenses Sw.) clarificado sobre a glicemia pós-prandial em humanos, após consumo de $25 \mathrm{~g}$ de carboidratos disponíveis provenientes de pão branco (aproximadamente $50 \mathrm{~g}$ de pão francês), e caracterizar o suco e a polpa de araçá quanto aos compostos fenólicos e capacidade antioxidante in vitro. Os resultados mostraram que o suco clarificado apresenta efeito positivo sobre a glicemia pós-prandial, causando redução da quantidade total de glicose absorvida, aumento no tempo para atingir a concentração sanguínea máxima de glicose, diminuição na velocidade de incremento da glicose e diminuição do incremento percentual da glicose. Tanto a polpa congelada como o suco clarificado se caracterizaram pelos altos teores de compostos fenólicos, capacidade antioxidante e proantocianidinas, entre as quais, foram detectados oligômeros (monômeros a tetrâmeros), pentâmeros, hexâmeros, heptâmeros, octâmeros, nonâmeros, decâmeros e polímeros, provavelmente associados aos efeitos observados in vivo.

Palavras-chave: araçá; glicemia pós-prandial; diabetes.

\section{Introduction}

Diets rich in fruits and vegetables, and therefore in phenolic compounds reduce the risk of cardiovascular disease and cancer. Phenolic compounds are the largest category of phytochemicals, and they are widely spread in the plant kingdom. They are derived from the shikimic acid and phenylpropanoid pathway. The largest groups of dietary phenolics are flavonoids, tannins, and phenolic acids. Phenolic acids include benzoic acids and derivatives (hydroxybenzoic, vanillic, gallic etc) and cinnamic acids and derivatives (coumaric, ferulic, caffeic, etc). Tannins are polymers of high molecular weight divided into hydrolysable tannins (polymers of gallic acid and ellagic acid), present in fruits such as strawberries and nuts, and condensed tannins (polymers of catechin or epicatechin) (MANACH et al., 2004).

Phenolic compounds are generally potent antioxidants. Several evidences have suggested that a diet rich in natural antioxidants, mainly phenolic compounds, can reduce the risk of diseases caused by oxidative stress in biological systems. Moreover, some of these compounds can inhibit the in vitro activity of enzymes involved in carbohydrate metabolism (PINTO; LAJOLO; GENOVESE, 2008; PINTO et al., 2009; RANILLA et al., 2008, 2009), whose possible effects on the prevention/treatment of type 2 diabetes mellitus (T2DM) are described below.

Diabetes Mellitus is a metabolic disorder of multiple etiologies characterized by chronic hyperglycemia and disturbances of proteins, carbohydrates, and lipids metabolism resulting from deficient insulin secretion, reduced sensitivity of peripheral tissues to the biological effects of insulin (WORLD..., 1999). In 2000, this disease affected about 171 million people

${ }^{1}$ Laboratório de Compostos Bioativos de Alimentos, Departamento de Alimentos e Nutrição Experimental, Faculdade de Ciências Farmacêuticas,

Universidade de São Paulo - USP, Av. Professor Lineu Prestes, 580, Bloco 14, CEP 05508-900, São Paulo, SP, Brasil, e-mail: genovese@usp.br

${ }^{*}$ Corresponding author 
worldwide, and it is estimated that this number will rise to at least 366 million in 2030 (WILD et al., 2004).

The most common complications of diabetes are metabolic disorders and infection. Hypertension is one of the macrovascular complications, but other microvascular problems can occur, such as retinopathy, nephropathy, and neuropathy, which are caused by oxidative stress generated by hyperglycemia episodes resulting in cell damage, followed by lipid peroxidation and inactivation of proteins (NISHIKAWA et al., 2000; ROLO; PALMEIRA, 2006).

Recent studies suggest that hyperglycemia triggers the formation of free radicals and oxidation-linked stress in capillary endothelial cells in the retina, in the renal glomerulus, and in peripheral nerves (BROWNLEE, 2005).

Treatments for T2DM aim at maintaining adequate glycemic control through a low-calorie diet and increased physical activity or through the use of medications. Due to the severity of diseases and side effects of traditional pharmacological therapies, the search for alternative therapies that may be an adjuvant treatment of T2DM is essential. Thus, inhibitors of $\alpha$-amylase and $\alpha$-glucosidase emerge as promising substances by reducing the absorption of glucose exerting potential effect on postprandial glucose reduction (PEREIRA, 2008).

Diets rich in carbohydrates such as starch, which are hydrolyzed by the two major digestive enzymes, $\alpha$-glucosidase, and $\alpha$-amylase are the main source of blood glucose. Alphaglucosidase is present in the ciliary membrane of small intestine and promotes the breakdown of starch and sucrose (cleavage of binding $\alpha-1,4$ and $\alpha-1,6)$ releasing glucose molecules to be absorbed. Alpha-amylase is present in salivary and pancreatic juice and is responsible for cleaving $\alpha-1,4$ bonds releasing dextrin, maltose, and maltotriose (BISCHOFF, 1994). Inhibition of these enzymes delays and prolongs the digestion of carbohydrates, thus reducing the rate of glucose absorption and consequently the sudden postprandial plasma glucose increase (TOELLER, 1994). Acarbose is an a-glycosidase inhibitor and has been widely used to control postprandial hyperglycemia in diabetic and pre diabetic individuals.

Plants have constituents with inhibitory activity against enzymes including polyphenols and glycoproteins (TUNDIS; LOIZZO; MENICHINI, 2010); for example, theaflavins and catechins which are present in green and black teas and have inhibitory properties of $\alpha$-glycosidase and $\alpha$-amylase in vitro (KOH et al., 2010). Accordingly, McDougall and Stewart (2005) also highlighted that anthocyanins are good $\alpha$-glycosidase inhibitors.

In general, the high antioxidant capacity of flavonoids can also be effective in reducing oxidative stress and progression of diabetes mellitus (SONG et al., 2005; KWON; VATTEM; SHETTY, 2006). Therefore, the aim of this study was to evaluate the effect of clarified araçá juice (Psidium guinnensis Sw.) on postprandial glucose after consumption of $25 \mathrm{~g}$ of available carbohydrate (from white bread) in humans and to characterize the chemical composition and phenolic content of araçá fruit juice and pulp.

\section{Materials and methods}

\subsection{Subjects}

Twenty three healthy individuals, 17 females and 6 males, with average age ( \pm SD) of $29 \pm 6$ years (range, 23-43 years), average body mass index (BMI) ( \pm SD) of $23.7 \pm 2.9 \mathrm{~kg} / \mathrm{m}^{2}$ (range, 19.2-30.4 kg/m ${ }^{2}$ ), and average systolic blood pressure of $110 \pm 12 \mathrm{~mm} \mathrm{Hg}$ and diastolic blood pressure of $68 \pm 7 \mathrm{~mm}$ $\mathrm{Hg}$ participated in this study. The subjects were recruited from among graduate students at the College of Pharmaceutical Sciences and the Chemistry Institute, University of São Paulo (USP). Exclusion criteria were: diabetes, overweight (BMI greater than 25), use of medication for the treatment of type 2 diabetes, hormone replacement therapy or patients undergoing treatment to reduce blood viscosity, use of vitamin/mineral supplements or antibiotics, smoking, pregnancy, and patients with gastrointestinal, liver, kidney, or bleeding disorders. This study was approved by the Human Research Ethics Committee of the University of São Paulo, CEP-UH/USP record: 937/09 - SISNEP and the Ethics Committee in Research of the College of Pharmaceutical Sciences, University of São Paulo (protocol CAAE: 0025.0.018.198-09). Informed consent was obtained from each research participant.

\subsection{Meals}

The frozen pulp of araçá, prepared in April 20, 2011, was acquired in the state of São Paulo, Brazil - Sitio do Bello - ready for consumption. The clarified juices were prepared homogenizing the frozen pulp using a blender, followed by centrifugation at $22.770 \mathrm{~g}$ for 40 minutes.

Each meal consisted of approximately $25 \mathrm{~g}$ of available carbohydrate as white bread (corresponding to one unit of white bread of approximately $50 \mathrm{~g}$ ), $300 \mathrm{~mL}$ of water (control), and clarified araçá juice; it was administered after 10-12 hours of fasting. All volunteers underwent both tests with water (control) and clarified araçá juice with an interval of 7 days. They were asked to avoid foods and beverages rich in polyphenols (chocolate, wine, red fruits, coffee, and tea) and alcoholic beverages in this period, especially on the day before the test. The test meals were consumed within 10 minutes maximum. The subjects were instructed to remain at rest in the supine position while blood samples were drawn (room temperature of $22^{\circ} \mathrm{C}$ ).

\subsection{Glucose analysis}

The study was conducted at the University of São Paulo Clinical Research Center(USP). The postprandial blood glucose levels were determined by measuring capillary blood glucose using a digital glucometer (Accu-Chek peforma) at 0 (immediately before consumption of bread), 15, 30, 45, 60, 90, and 120 minutes after the test meal intake (JOSSE et al., 2007). Blood was collected in heparinized tubes. To obtain plasma, the samples were immediately centrifuged for 15 minutes at $1500 \mathrm{~g}$ $\left(4^{\circ} \mathrm{C}\right)$, and plasma was stored at $-80^{\circ} \mathrm{C}$. Results were expressed as mean \pm standard deviation. 
The area under curve (AUC) for glucose was calculated using the trapezoidal rule to determine the reduction of the glycemic response. The AUC was obtained by numerical calculation of the integral of the curve, calculated using the software Graphpad Prism v. 5.0, expressed in $\mathrm{mg} / \mathrm{dL}$. The following variables in the curves of glucose were analyzed: glucose baseline (GB), obtained at time zero; glucose peak value (GPV), defined as the highest value above the baseline observed after ingestion of the meal and expressed in $\mathrm{mg} / \mathrm{dL}$; absolute increase of glucose (AIg), defined as the absolute difference between the maximum value obtained after stimulation of glucose GPV and GB, expressed in $\mathrm{mg} / \mathrm{dL}$ $(\mathrm{AIg}=\mathrm{GPV}-\mathrm{GB}) ;$ glucose incremental percentage $(\mathrm{GIP})$, defined as the ratio between the AIg and GB, expressed in percentage terms $(\mathrm{GIP}=(\mathrm{AIg} / \mathrm{GB}) \times 100)$. Glucose incremental velocity (GIV) is defined as the ratio between AIg and the time of maximum blood glucose concentration, expressed in $\mathrm{mg} / \mathrm{mL}$ minute (GIV = AIg/peak time).

\subsection{Chemical characterization}

Moisture, $\mathrm{pH}$, total soluble solids, and titratable acidity were determined according to the Association of Official Agricultural Chemists (ASSOCIATION..., 1997). Totals sugars were determined according to the method described by Dubois et al. (1956).

Quantification of proanthocyanidins: proanthocyanidins quantification was performed according to the chromogenic method described by Porter, Hrstich and Chan (1986). An aliquot of $2.5 \mathrm{~mL}$ of the Porter reagent was added to $250 \mu \mathrm{L}$ of suitably diluted extract in a test tube. Similarly, a standard curve was prepared using quebracho tannin ranging from 0 to $2.4 \mathrm{mg} / \mathrm{mL}$ (QT Unitan, Buenos Aires, Argentina). The tubes were capped and kept in a water bath at $95{ }^{\circ} \mathrm{C}$ for 15 minutes; after mild agitation, the absorbance was measured at $540 \mathrm{~nm}$. The amount of proanthocyanidins was calculated from the standard curve and expressed in $\mathrm{g}$ of tannin (quebracho) equivalent (TQE) per $300 \mathrm{~mL}$ of juice. Proanthocyanidins content of the araça commercial frozen pulp was also determined by the DMAC assay, using 4-dimethylaminocinnamaldehyde according to Prior et al. (2010). The content was estimated using the standard curve of procyanidin B2 (HPLC, purity >99\%, Extrasynthèse) ranging from 5 to $50 \mu \mathrm{g} / \mathrm{mL}$. The analyses were performed in triplicate, and the results were expressed as $\mathrm{mg}$ of procyanidin B2 equivalents/100 g sample (DW).

Identification and Quantification of Sugar: Sugar composition was determined after extraction of the pulp in $80 \%$ aqueous ethanol. An aliquot of the extract was heated to $70^{\circ} \mathrm{C}$ in a water bath, followed by agitation on a vortex mixer and centrifugation. The supernatant $(1 \mathrm{~mL})$ was evaporated to dryness in using an evaporator (Reacti-therm III) for 1 hour at $40^{\circ} \mathrm{C}$. The dry residue was resuspended in water and filtered in a PTFE filter (Millipore Ltd., Bedford, MA). Sugar content assays were performed by HPLC with a refractometer detector according to Bogdanov, Martin and Lüllmann (1997). The following sugars were assayed and compared: glucose, fructose, sucrose, and polysaccharides. The analyses were performed in triplicate, and the sugar content was expressed as $\mathrm{mg} / 100 \mathrm{~g}$ (DW).
Sample preparation for proanthocyanidins analysis by HPLC-fluorescence and UPLC-MS: Lyophilized frozen pulp powders were added to the extractor solvent $(0.5 \%$ acetic acid in $70 \%$ aqueous acetone), and the mixture was kept at $37^{\circ} \mathrm{C}$ overnight and then centrifuged for 5 minutes at $3500 \times \mathrm{g}$. The dry residue was rextracted by agitation on a vortex mixer for 2 minutes, followed by sonication at $37^{\circ} \mathrm{C}$ for 10 minutes. After centrifugation, supernatants were combined and filtered in a Whatman grade No. 1 filter paper and concentrated using a rotary evaporator (Rotavapor RE 120; Büchi, Flavil, Sweden) to remove acetone. The samples were semi-purified using Sephadex LH-20 cartridges for solid phase extraction, which were conditioned with $50 \%$ aqueous acetone, methanol, and water. The compounds were eluted with $70 \mathrm{~mL}$ of $0.5 \%$ acetic acid in $70 \%$ aqueous acetone. The samples were evaporated to dryness, resuspended in $2 \mathrm{~mL}$ of $0.5 \%$ acetic acid in $70 \%$ aqueous acetone, and injected in a HPLC or UPLC.

Instrumentation and chromatographic conditions for ellagitannins (ETs) and proanthocyanidins (PACs) identification: ETs from araçá commercial frozen pulp were identified according to the methodology described by Gasperotti et al. (2010). Separation was carried out with a Waters Aquity UPLC system equipped with a UV-vis Waters PDA (Waters Corp., Milford, MA) and a mass spectrometer with an electrospray ionization system (ESI) and MassLynx Software 4.1 (Waters Corp.). A $50 \mathrm{~mm} \times 2.1 \mathrm{~mm}$ i.d., $1.7 \mu \mathrm{m}$, endcapped reversedphase AcquityTM UPLC BEH C18 (Waters) column was used. The solvents were A ( $1 \%$ formic acid in water) and B (acetonitrile). UPLC-MS analysis was performed in negative mode under the following conditions: capillary voltage $3 \mathrm{kV}$, source temperature $100^{\circ} \mathrm{C}$, desolvation temperature $350^{\circ} \mathrm{C}$, and desolvation gas flow $\left(\mathrm{N}_{2}\right) 650 \mathrm{~L} / \mathrm{h}$. The $\mathrm{m} / \mathrm{z}$ range was $50-3000$ Da. Ellagic acid and ellagitannins were identified using UV detection at $260 \mathrm{~nm}$. The analyses were performed in triplicate, and the content of ellagic acid and ellagitannins was expressed as $\mathrm{mg}$ of ellagic acid equivalents/100 $\mathrm{g}$ sample (DW).

PACs identification analyses were determined according to Robbins et al. (2009). Separation was carried out with a Waters Aquity UPLC system equipped with fluorescence detectors. The mobile phases consisted of (A) dichloromethane/acetic acid and (B) methanol/acetic acid. The UV detection was set to $280 \mathrm{~nm}$. Fluorescence was detected at an excitation wavelength of $230 \mathrm{~nm}$ and an emission wavelength of $321 \mathrm{~nm}$. Normal phase separations were performed using a Develosil Diol $100 \AA$ ( 250 $\times 4.6 \mathrm{~mm}, 5 \mu \mathrm{m}$ particle size) purchased from Phenomenex (Torrance, CA, USA). The analyses were performed in triplicate.

DPPH (2,2-diphenyl-1-picrylhydrazyl) scavenging ability. The antioxidant capacity was evaluated using the method of DPPH free radical scavenging in microplates (BRANDWILLIAMS; CUVELIER; BERSET, 1995). The results were expressed as $\mu \mathrm{mol}$ of Trolox equivalent (TE) per $300 \mathrm{~mL}$ of juice.

Ferric reducing antioxidant power - FRAP. FRAP was determined according to Benzie and Strain (1996) with modifications. FRAP reagent was prepared at a concentration of 10:1:1 with the following solutions: (a) $300 \mathrm{mM}$ sodium acetate buffer (dynamic), pH 3.6, (b) solution of $40 \mathrm{mM}$ 2,4,6-tripiridils-triazine (TPTZ - Flucka Chemicals Switzerland) in $10 \mathrm{mM}$ 
hydrochloric acid (VETEC), and (c) $20 \mathrm{mM}$ ferric chloride solution (Synth). A standard curve was prepared using 6-hydroxy-2, 5,7,8-tetrametilchroman-2-carboxylic acid (Trolox - Flucka Chemicals Switzerland) at a concentration of $50-400 \mathrm{mM}$. Absorbance was measured at $593 \mathrm{~nm}$. The results were expressed as $\mu \mathrm{mol}$ of Trolox equivalent (TE) per $300 \mathrm{~mL}$ of clarified juice.

Oxygen Radical Absorbance Capacity (ORAC) Assay. The determination was performed according to the method of Dávalos, Gómez-Cordovés and Bartolomé (2004). The results were expressed as $\mu \mathrm{mol}$ of Trolox equivalent (TE) per $300 \mathrm{~mL}$ of juice.

Determination of the total phenolic content. The content of phenolic compounds was determined according to Singleton, Orthofer and Lamuela-Raventos (1999) with some modifications (GENOVESE et al., 2003) using the Folin Ciocalteu reagent. The results were expressed as mg catechin equivalent (CE) per $300 \mathrm{~mL}$ of juice.

\subsection{Analysis of results}

The results were analyzed using the Statistica version 10.0 (StatSoft Inc. Tulsa, USA). Comparison of means was performed by ANOVA $(\mathrm{P}<0.05)$, LSD (least significant difference), and Tukey's test.

\section{Results and discussion}

The Brazilian cerrado is an important ecosystem with a wide variety of fruit species. Some of them are edible and have a great value to local population as part of their eating habits. Most of them are rich in pigments and present distinctive aromas, but little is known about their chemical and biochemical characteristics (CASTRO; KAUFFMAN, 1998). Araçá is a berryshaped fruit of approximately $11 \mathrm{~g}$, moisture content of $80.4 \%$ (pulp) and 77\% (peel), and caloric value of $78.2 \mathrm{kcal}$ in $100 \mathrm{~g}$ of pulp and $90.8 \mathrm{kcal}$ in $100 \mathrm{~g}$ of peel. Total solids content is $10.7^{\circ} \mathrm{Brix}$ in the pulp and $11^{\circ} \mathrm{Brix}$ in the peel, and $\mathrm{pH}$ is 3.99 and 3.76 for the pulp and peel, respectively (DAMIANI et al., 2011).

In the present study, the araçá commercial frozen pulp was evaluated in terms of sugar content. Sucrose, glucose, fructose, and polysaccharides were detected in the following amounts respectively: $62.7,60.7,79.0$ and $22.1 \mathrm{mg} / 100 \mathrm{~g}(\mathrm{DW})$.

The total solid content of the clarified araçá juice was $6.63 \mathrm{~g} / 100 \mathrm{~mL}$ juice. The soluble solid ('Brix) was 8.5 , and the $\mathrm{pH}$ was 4.01 . The total sugar content and titratable acidity were $13.7 \mathrm{~g}$ equivalents glucose $/ 100 \mathrm{~mL}$ juice and $8.9 \mathrm{~g} / 100 \mathrm{~mL}$ juice, respectively (Table 1 ).

Generally, the amount of sugar is higher in pulps comparing to that of peel or seeds. Sugar content detected in fruits can vary according to harvest time. Fruits harvested during the winter have lower amount of sugar due to the short photoperiod (BARROS; FINGER; MAGALHÃES, 1996).

The main polysaccharides found in fruits belong to the class of pectins and can be extracted from the cell wall. They are heteropolysaccharides formed by a linear chain of $\alpha$-D-
Table 1. Chemical characterization of clarified araçá (Psidium guineensis Sw.) juice prepared from araçá commercial frozen pulp and administered to the volunteers.

\begin{tabular}{lc}
\hline Totals solids (g/100 mL juice) & $6.6 \pm 0.07$ \\
Soluble solids ( ${ }^{\circ}$ Brix) & $8.5 \pm 0.1$ \\
$\mathrm{pH}$ & $4.01 \pm 0.12$ \\
Total sugar (g equivalents glucose/100 mL juice) & $13.7 \pm 0.06$ \\
Titratable acidity (g/100 mL juice) & $8.85 \pm 0.02$ \\
Proanthocyanidins ( $\mathrm{g} \mathrm{TQE} / 300 \mathrm{~mL}$ of juice) & $1.480 \pm 0.018$ \\
Phenolics content $(\mathrm{mg}$ of $\mathrm{CE} / 300 \mathrm{~mL}$ of juice) & $546 \pm 13$ \\
DPPH ( $\mu \mathrm{mol} \mathrm{TE} / 300 \mathrm{~mL}$ of juice) & $1453 \pm 29$ \\
FRAP $(\mu \mathrm{mol} \mathrm{TE} / 300 \mathrm{~mL}$ of juice) & $1.85 \pm 0.12$ \\
ORAC ( $\mu \mathrm{mol} \mathrm{TE} / 300 \mathrm{~mL}$ of juice) & $7485 \pm 77$ \\
\hline
\end{tabular}

The results are expressed as mean \pm standard deviation. $\mathrm{TQE}=$ Tannin (quebracho) equivalents; $\mathrm{CE}=$ catequin equivalents; $\mathrm{TE}=$ Trolox equivalents.

galacturonic acid and its O-methylated derivatives. Galacturonic acid is generally esterified. The esterification degree and the number and distribution of rhamnose residues depend on the source of pectin and strongly influence the solubility and ability to form gel (CUNHA; PAULA; FEITOSA, 2009).

Pectins are mainly found in the peel of fruits (CUNHA; PAULA; FEITOSA, 2009), which is consistent with the low value found in this sample. Since the fruit pulp is produced by pressure to separate the seed and the epicarp, components of the fruit peel are poorly extracted.

Proanthocyanidins are polymeric flavonoid compounds composed of flavan-3-ol subunits. They are found naturally in many foods, red wine, cocoa, grape seed, and green tea (WALLACE; GIUSTI, 2010). Proanthocyanidins in araçá frozen pulp were determined by the DMAC assay developed by Prior et al. (2010), which is faster, more sensitive and simpler than other methods, and it has been extensively used for cranberries. Araçá commercial frozen pulp had $975 \pm 2 \mathrm{mg}$ procyanidin $\mathrm{B} 2$ equivalent $/ 100 \mathrm{~g} \mathrm{DW}$, and this amount is around 5 times lower than that found in strawberry, blueberry, and cranberry, which are known as rich-PACs fruits (WANG et al., 2011).

Figure 1 shows proanthocyanidins profile of araçá commercial frozen pulp. The oligomers varied from monomers to tetramers and represent the majority of the proanthocyanidins found in the sample. Pentamers, hexamers, heptamers, octamers, nonamers, decamers, and polymers were also detected. Fluorescence was the main detection method used for identification and quantification and provides a stronger signal than UV absorption for procyanidins (LAZARUS et al., 1999).

Epidemiological studies have indicated that foods rich in PACs have beneficial effects against cardiovascular disease. In vivo and in vitro experiments have demonstrated that the intestinal absorption of lipids, secretion of chylomicrons by intestine, and secretion of VLDL in the liver are repressed by the action of PACs, leading to a reduction of hyperlipidemia (PAJUELO et al., 2011). 
FLD1 A, Ex=230, Em=321 (27SEPT11_MARCELA 27SEPT11_MARCELA2_42।077-1701.D)

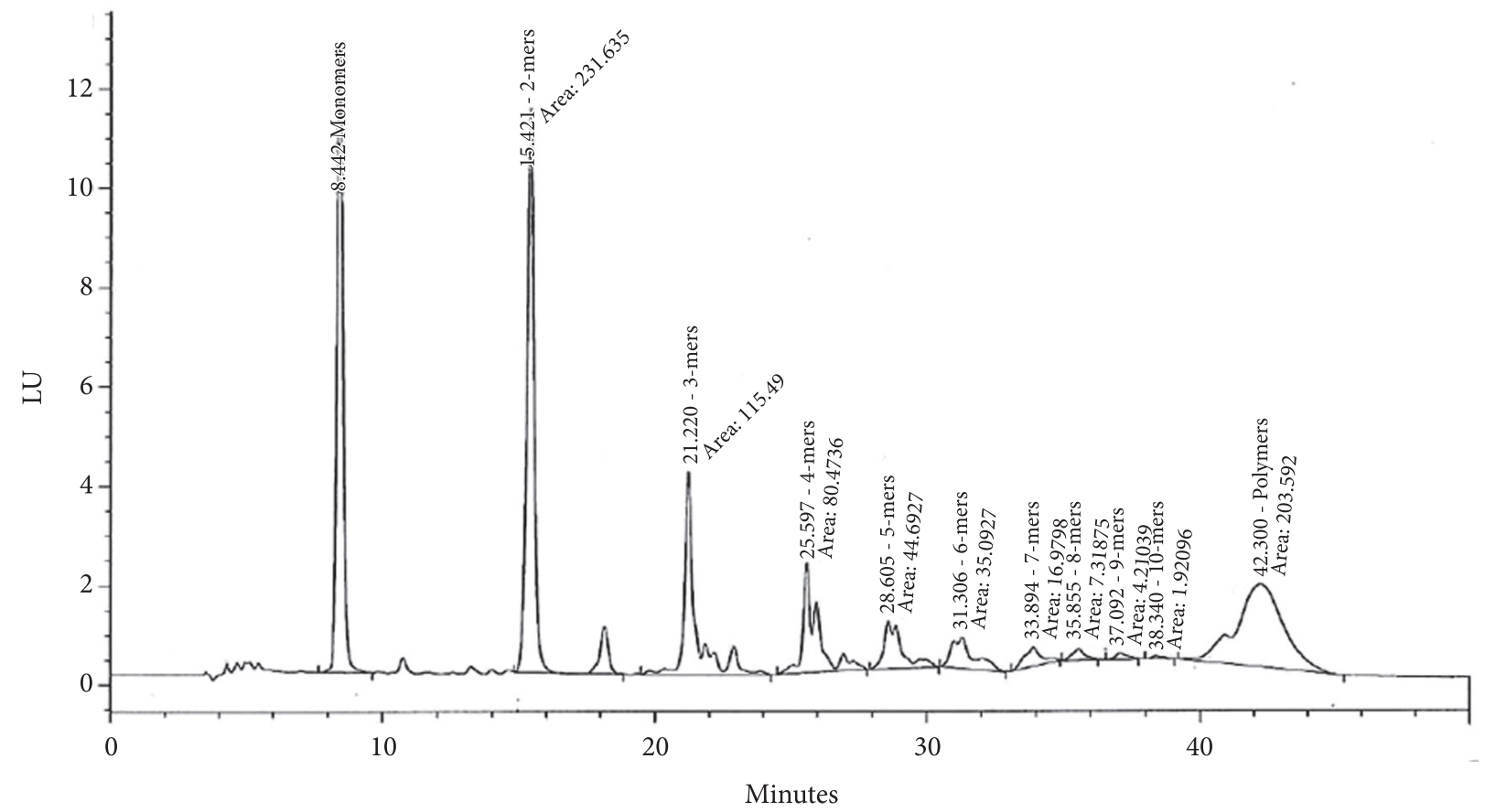

Figure 1. Chromatography profile of proanthocyanidins of araçá commercial frozen pulp at an excitation wavelength of $230 \mathrm{~nm}$ and an emission wavelength of $321 \mathrm{~nm}$.

Although araçá cannot be considered a very rich-PACs fruit comparing to the main sources, such as strawberry, it had a high amount of ellagitannins (ETs) (Table 2) and, in comparison to some ordinary fruits consumed in Brazil, such as mango, pineapple, passion fruit, and grape (ABE; LAJOLO; GENOVESE, 2012), it can be considered a much richer ETsource.

Table 2 shows the ellagitannins identified in araçá commercial frozen pulp. It is known that the occurrence of ETs is very limited; they can be found in fruits such as pomegranate, strawberry, cranberry, blueberry, and blackberry and also some nuts (KÄHKÖNEN; HOPIA; HEINONEN, 2001). Among the Brazilian fruits, the main sources belong to the Myrtaceae family, such as cambuci, camu camu, jabuticaba, and araçá (ABE; LAJOLO; GENOVESE, 2012). Dietary ellagic acid and ETs are metabolized by human microbiota to dibenzopyran6-one known as urolithins (CERD et al., 2005). Sanguiin H-6, lambertianin $\mathrm{C}$, and various ellagic acid derivatives (acylated and/or glycosylated ellagic acid moieties) have been identified in Rubus fruit, but several studies have reported unidentified ellagitannins due to the diverse and complex nature of their structures (HAGER et al., 2008). Sanguiin H-6 is also present in strawberries (CERD et al., 2005), but free ellagic acid and its glycosides are minor constituents as compared to ellagitannins (ZAFRILLA et al., 2001).

This is the very first time that hydrolyzed (ETs) and condensed tannins (PACs) from araçá are characterized and quantified. These compounds have grown in importance in the field of nutrition and health due to their effects on the gut microbiota and the positive effects of metabolites on several parameters such as vasodilation, reduced sensitivity of low-
Table 2. Identification and quantification (mg of ellagic acid equivalents/100 g sample DW) of ellagitannins present in the araçá commercial frozen pulp.

\begin{tabular}{ccclc}
\hline & RT & {$[\mathrm{M} / \mathrm{Z}]$} & \multicolumn{1}{c}{ Compound } & Amount \\
\hline 1 & 7.7 & $603 ; 449 ; 301$ & Ellagic acid & 3.0 \\
2 & 3.7 & $783 ; 649$ & Sanguiina H-10 isomer (1) & 2.5 \\
3 & 3.9 & $783 ; 649$ & Sanguiina H-10 isomer (2) & 6.9 \\
4 & 5.0 & $783 ; 649$ & Sanguiina H-10 isomer (3) & 9.0 \\
5 & 4.4 & $934 ; 858 ; 1235 ; 469$ & Sanguiina H-6 (2) & 4.6 \\
6 & 5.7 & $934 ; 858 ; 1235 ; 469$ & Sanguiina H-6 (3) & 2.7 \\
7 & 6.8 & $934 ; 858 ; 1235 ; 469$ & Sanguiina H-6 (4) & 1.2 \\
8 & 7.2 & $934 ; 858 ; 1235 ; 469$ & Sanguiina H-6 (6) & 1.2 \\
9 & 8.8 & $505 ; 1011$ & Ellagitannin unknown & 2.0 \\
\hline
\end{tabular}

density lipoproteins, and modulation of several reactions associated with inflammation (AURA et al., 2012; BEECHER, 2004).

It has been previously shown that phenolic compounds from araçá are able to inhibit $\alpha$-amylase and $\alpha$-glucosidase in vitro (GONÇALVES; LAJOLO; GENOVESE, 2010). Therefore, a clarified araçá juice was prepared in order to eliminate the effect of fiber and evaluate the possible action of araçá phenolics on human enzymes.

Due to the possible association of phenolic substances with dietetic fibers, the clarified juice was previously analyzed to ensure that it remained a rich source of these compounds after fiber removal. The clarified araçá juice was shown to be a source of phenolic compounds with an excellent antioxidant capacity 
in vitro. Table 1 shows the results obtained in the analysis of the antioxidant potential by three different methods. The scavenging capacity of DPPH• was $1453 \mu \mathrm{mol}$ TE per $300 \mathrm{~mL}$ of juice. The ferric reducing power (FRAP) was $1.85 \mu \mathrm{mol}$ TE per $300 \mathrm{~mL}$ juice. The antioxidant capacity measured by the ORAC method was $7485 \mu \mathrm{mol}$ TE per $300 \mathrm{~mL}$ of juice. The ORAC is a method with greater sensitivity for evaluation of antioxidant capacity than other methods. Proanthocyanidins and total phenolics contents of the clarified araçá juice were $1480 \mathrm{~g}$ of TQE and $514 \mathrm{mg}$ of CE per $300 \mathrm{~mL}$ of juice, respectively, confirming their strong presence after fiber separation.

\subsection{Effect of juice clarification on postprandial glycemia}

When araçá juice was taken together with $50 \mathrm{~g}$ of white bread, a significant effect on glycemia was observed. Glucose baseline was similar in both tests (average of $86 \pm 6 \mathrm{mg}$ of glucose/dL) when the volunteers consumed water or araçá juice with $25 \mathrm{~g}$ of available carbohydrate. The postprandial glycemic curves of clarified araçá juice and control tests are shown in Figure 2. The maximum blood concentration of glucose in the juice test was lower when compared to the control test.

The values of AUC (area under curve), AIg (absolute increase of glucose), GIV (glucose incremental velocity), and GIP (glucose incremental percentage) can be seen in Table 3.

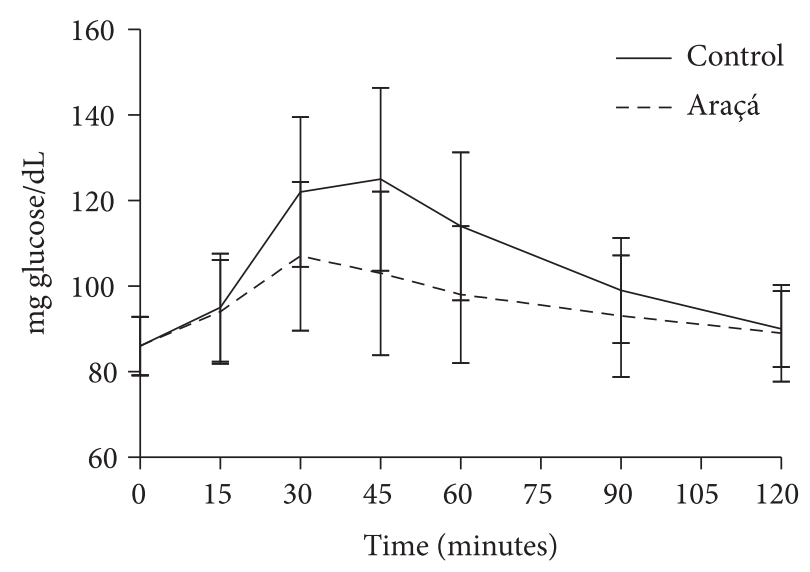

Figure 2. Postprandial blood glucose at 0, 15, 30, 45, 60, 90, and 120 minutes after test meals: araçá: bread + clarified araçá juice $(300 \mathrm{~mL})$ and control, bread + water $(300 \mathrm{~mL})$. Mean \pm standard deviation $(\mathrm{n}=23)$.

Table 3. Effect of clarified araçá juice on postprandial glucose of healthy volunteers $(n=23)$, compared to water as the control: Area under curve (AUC), Absolute increase of glucose (AIg), Glucose incremental velocity (GIV), and Glucose incremental percentage (GIP).

\begin{tabular}{lcc}
\hline \multicolumn{1}{c}{ Parameters } & Control & Araçá juice \\
\hline AUC (mg glucose/dL) & $2340 \pm 909^{\mathrm{a}}$ & $1437 \pm 929^{\mathrm{b}}$ \\
AIg (mg glucose/dL) & $42 \pm 15^{\mathrm{a}}$ & $27 \pm 14^{\mathrm{b}}$ \\
GIV (mg glucose/mL minute) & $1.12 \pm 0.35^{\mathrm{a}}$ & $0.77 \pm 0.51^{\mathrm{b}}$ \\
GIP $(\%)$ & $49 \pm 16^{\mathrm{a}}$ & $32 \pm 17^{\mathrm{b}}$ \\
\hline
\end{tabular}

The results are expressed as mean \pm standard deviation $(n=23)$. Means in the same row with different letters are significantly different $(\mathrm{p}<0.05)$.
The AUC of araçá juice was significantly different from that of the control ( $p<0.05$ ). The GIV and GIP of araçá juice were significantly different from those of the control. The clarified araçá juice showed reduction in AUC and delay in the time of maximum blood glucose concentration compared to those of the control.

A possible mechanism to explain the observed effects is the inhibition of the enzymes responsible for the metabolism of carbohydrates, $\alpha$-amylase, and $\alpha$-glucosidase by the polyphenols present in araçá juice. Inhibition of these enzymes by the purified extracts of the Brazilian native fruits has already been observed in vitro (GONÇALVES; LAJOLO; GENOVESE, 2010). Anthocyanins and ellagitannins present in raspberries and strawberries have been associated with inhibition of the enzymes a-amylase and a-glucosidase, respectively (McDOUGALL; STEWART, 2005). In a study carried out by Hargrove et al. (2011), $1.5 \mathrm{mg}$ of phenolics/mL of the tannin fraction and $12 \mathrm{mg}$ phenolic/mL of the single flavonoids fraction (free tannins) were able to inhibit $91 \%$ and $29 \%$ of $\alpha$-amylase enzyme in vitro, respectively.

A glass of araçá juice had a very significant effect on postprandial hyperglycemia reducing the area under the glucose curve of healthy subjects by $43 \pm 28 \%$ less than that of a glass of water. Herrmann, Schatz and Pfeiffer (1998) observed that acarbose was able to reduce the area under the glucose curve of diabetic patients in $28 \%$. The excessive inhibition of a-amylase can result in abnormal fermentation of undigested starch in the colon (HORII et al., 1987). In fact, a high inhibition of a-amylase is the major obstacle to the wide spread use of current drugs acting as $\alpha$-glucosidase inhibitors, such as acarbose, causing bloating, flatulence, meteorism and diarrhea (BISCHOFF, 1994). However, araçá juice caused no adverse effects, according to the volunteer reports.

Acarbose, an a-glucosidase inhibitor, is an enzyme responsible for degrading disaccharides and polysaccharides in the small intestine, commonly used in the treatment of diabetes mellitus. In a study by Gonçalves, Lajolo and Genovese (2010), which evaluated in vitro inhibitory effect of the enzymes $\alpha$-glucosidase and $\alpha$-amylase by acarbose and several phenolic compounds, phenolics were able to inhibit both enzymes and were more effective than acarbose in inhibiting a-glucosidase.

Postprandial hyperglycemia is known as an indicator of cardiovascular risk and as a major limiting factor to achieve good metabolic control in diabetic patients (JOSSE et al., 2007). The primary aim of treatment for patients with type 2 diabetes is to control the levels of postprandial glucose. Thus, efforts are directed towards diet control, which is these patients' main medical nutritional therapy. However, even strict obedience to the diet cannot prevent postprandial hyperglycemia in the long term in most patients. In patients with type 2 diabetes, the postprandial response is caused by abnormal insulin secretion altered by inadequate peripheral utilization of glucose (insulin resistance) and the inability to adequate suppression of hepatic glucose production (MILECH; CHACRA; KAYATH, 2001).

After a meal, blood glucose levels rise and the same is counterbalanced by a quick release of insulin, followed by a 
slower phase of release of this hormone, providing a longer duration of insulin activity (MILECH; CHACRA; KAYATH, 2001). Blood glucose rises ten minutes after food ingestion, and it reaches its maximum within 60 minutes and usually returns to baseline within 2 to 3 hours (GROSS; FERREIRA; OLIVEIRA, 2003). However, soft drinks and foods such as fruit juice, have a rapid increase in maximum glucose concentration followed by high insulin secretion and a sudden reduction in the maximum blood glucose concentration (BRAND-MILLER et al., 2009).

Araçá juice presented an IVg lower than that of the control, i.e., in the present study, the maximum blood concentration of glucose took longer to occur in this juice than in the control group. The delay in the maximum blood glucose concentration is part of the strategy for risk reduction and control of diabetes and cardiovascular disease. The rapid increase in blood glucose levels causes a rapid increase in insulin levels. Insulin promotes glycogen formation on hepatic and skeletal muscle cells; it also promotes the synthesis of fatty acids and lipid accumulation in skeletal muscle and liver, which is associated with reduced insulin sensitivity (BARRET; UDANI, 2011).

Studies in diabetic and no diabetic patients showed that the risk of death from cardiovascular disease and even death from other causes is increased in subjects with altered 2 hour-glucose and at the same time have normal fasting glucose (GROSS; FERREIRA; OLIVEIRA, 2003). Thus, it is of fundamental importance to study the control of postprandial glycemia, especially the possibility of achieving such control through dietetic compounds.

This study tested an araçá juice that was selected from previous studies (GENOVESE et al., 2008; GONÇALVES; LAJOLO; GENOVESE, 2010), which showed that this fruit is distinguished by its high content of phenolic compounds, in vitro antioxidant capacity, and inhibition of the carbohydratehydrolyzing enzymes. The success of human studies depends entirely on the sustained cooperation of its participants. It is ideal to have a large number of participants because this gives analysis more statistical power. Often, participants are difficult to contact or locate for follow-up assessments, and retaining participants is one of the biggest challenges when conducting research involving humans (COTTER et al., 2005). In fact, the number of volunteers in this study is not adequate to determine the quantitative effect of the intervention, but is enough to indicate the qualitative profile of the effect of the araçá clarified juice on glycemia postprandial. The results obtained so far are very promising and indicate the potential of araçá to help in the prevention/treatment of postprandial hyperglycemia in both diabetic and not diabetic individuals.

\section{Conclusion}

The introduction of new foods in the diet makes it less monotonous and more nutritious. Araçá juice is a good source of nutrients and has good antioxidant capacity. The high acceptability of the juice by the volunteers in this study indicates that it could be easily introduced in the habitual diet. Araçá juice attenuates postprandial glycemia, which is very important for individuals who experience hyperglycemia after consumption of foods rich in available carbohydrates.

\section{Acknowledgements}

The authors are grateful and to FAPESP, CNPq, and CAPES for the financial support and to the volunteers who participated in this study.

\section{References}

ABE, L. T.; LAJOLO, F. M.; GENOVESE, M. I. Potential dietary sources of ellagic acid and other antioxidants among fruits consumed in Brazil: jabuticaba (Myrciaria jaboticaba (Vell.) Berg). European Journal of Nutrition, v. 92, p. 1679-87, 2012.

ASSOCIATION OF OFFICIAL ANALYTICAL CHEMISTS - AOAC. Official Methods of Analysis of Association of Official Analytical Chemists. Arlington: AOAC, 1997.

AURA, A. M. et al. Characterization of microbial metabolism of Syrah grape products in an in vitro colon model using targeted and non-targeted analytical approaches. European journal of nutrition, 2012. Epub ahead of print. PMid:22699306. http://dx.doi. org/10.1007/s00394-012-0391-8

BARRET, M. L.; UDANI, J. K. A proprietary alpha-amylase inhibitor from white bean (Phaseolus vulgaris): A review of clinical studies on weight loss and glycemic control. Nutrition Journal, v. 10, p. 24, 2011. PMid:21414227 PMCid:3071778. http://dx.doi. org/10.1186/1475-2891-10-24

BARROS, R. S.; FINGER, F. L.; MAGALHÃES, M. M. Changes in non-structural carbohydrates in developing fruit of Myrciaria jabuticaba. Scientia Horticulturae, v. 66, p. 209-215, 1996. http:// dx.doi.org/10.1016/S0304-4238(96)00910-7

BEECHER, G. R. Proanthocyanidins: Biological Activities Associated with Human Health. Pharmaceutical Biology, v. 42, p. 2-20, 2004. http://dx.doi.org/10.3109/13880200490893474

BENZIE, I. F. F.; STRAIN, J. J. The ferric reduncing ability of plasma (FRAP) as a measure of "antioxidant power": The FRAP assay. Analytical biochemistry, v. 239, p. 70-76, 1996. PMid:8660627. http://dx.doi.org/10.1006/abio.1996.0292

BISCHOFF, H. Pharmacology of a-glucosidase inhibition. European Journal of Clinical Investigation, v. 24, n. 3, p. 3-10, 1994. PMid:8001624.

BOGDANOV, S.; MARTIN, P.; LÜLLMANN, C. Harmonised methods of the European Honey Commission. Apidologie, extra issue, p. 1-59, 1997.

BRAND-MILLER, J. C. et al. Glycemic index, postprandial glycemia, and the shape of the curve in healthy subjects: analysis of database of more than 1000 foods. American Journal of Clinical Nutrition, v. 89, p. 97-105, 2009. PMid:19056599. http://dx.doi.org/10.3945/ ajcn.2008.26354

BRAND-WILLIAMS, W.; CUVELIER, M. E.; BERSET, C. Use of free radical method to evaluate antioxidant activity. LWT- Food Science and Technology, v. 28, p. 25-30, 1995.

BROWNLEE, M. The pathobiology of diabetic complications: a unifying mechanism. Diabetes, v. 54, p. 1615-1625, 2005. PMid:15919781. http://dx.doi.org/10.2337/diabetes.54.6.1615

CASTRO, E. A.; KAUFFMAN, J. B. Ecosystem structure in the Brazilian cerrado: a vegetation gradient of aboveground biomass, root mass and consumption by fire. Journal of Tropical Ecology, v. 14, p. 263-284, 1998. http://dx.doi.org/10.1017/S0266467498000212

CERD, B. et al. Identification of urolithin A as a metabolite produced by human colon microflora from ellagic acid and related compounds. Journal of Agricultural and Food Chemistry, v. 53, 
p. 5571-5576, 2005. PMid:15998116. http://dx.doi.org/10.1021/ jf050384i

COTTER, R. B. et al. Contacting participants for follow-up: how much effort is required to retain participants in longitudinal studies? Evaluation and Program Planning, v. 28, p. 15-21, 2005. http:// dx.doi.org/10.1016/j.evalprogplan.2004.10.002

CUNHA, P. L. R.; PAULA, R. C. M.; FEITOSA, J. P. A. Polissacarídeos da biodiversidade brasileira: uma oportunidade de transformar conhecimento em valor econômico. Química Nova, v. 32, p. 649-660, 2009. http://dx.doi.org/10.1590/S010040422009000300009

DAMIANI, C. et al. Characterization of fruits from the savanna: Araçá (Psidium guinnensis Sw.) and Marolo (Annona crassiflora Mart.). Ciência e tecnologia de alimentos, v. 31, n. 3, p. 723-729, 2011. http://dx.doi.org/10.1590/S0101-20612011000300026

DÁVALOS, A.; GÓMEZ-CORDOVÉS, C.; BARTOLOMÉ, B. Extending applicability of the oxygen radical absorbance (ORAC) assay. Journal of Agricultural and Food Chemistry, v. 52, p. 48-54, 2004. PMid:14709012. http://dx.doi.org/10.1021/jf0305231

DUBOIS, M. et al. Colorimetric method for determination of sugars and related substances. Analytical Chemistry, v. 28, n. 3, p. 350-356, 1956. http://dx.doi.org/10.1021/ac60111a017

GASPEROTTI, M. et al. Profiling and accurate quantification of rubus ellagitannins and ellagic acid conjugates using direct UPLC-Q-TOF HDMS and HPLC-DAD analysis. Journal of Agricultural and Food Chemistry, v. 58, p. 4602-16, 2010. PMid:20353173. http://dx.doi. org/10.1021/jf904543w

GENOVESE, M. I. et al. Determinação do conteúdo de fenólicos totais em frutas. Revista Brasileira de Ciências Farmacêuticas, v. 39, n. 3, p. 67-69, 2003.

GENOVESE, M. I. et al. Bioactive Compounds and Antioxidant Capacity of Exotic Fruits and Commercial Frozen Pulps from Brazil. Food Science and Technology International, v. 14, n. 3, p. 207-214, 2008. http://dx.doi.org/10.1177/1082013208092151

GONÇALVES, A. E. S. S.; LAJOLO, F. M.; GENOVESE, M. I. Chemical composition and antioxidant/antidiabetic potential of Brazilian native fruits and commercial frozen pulps. Journal of Agricultural and Food Chemistry, v. 58, p. 4666-4674, 2010. PMid:20337450. http://dx.doi.org/10.1021/jf903875u

GROSS, J. L.; FERREIRA, S. R. G.; OLIVEIRA, J. E. Glicemia Posprandial. Arquivos Brasileiros de Endocrinologia \& Metabologia, v. 47, n. 6 , p. 728-738, 2003.

HAGER, T. J. et al. Ellagitannin composition of blackberry as determined by HPLC-ESI-MS and MALDI-TOF-MS. Journal of Agricultural and Food Chemistry, v. 56, p. 661-669, 2008. PMid:18211030. http://dx.doi.org/10.1021/jf071990b

HARGROVE, J. L. et al. Inhibition of aromatase and $\alpha$-amylase by flavonoids and proanthocyanidins from Sorghum bicolor bran extracts. Journal of Medicinal Food, v. 14, n. 7-8, p. 799-807, 2011. PMid:21612457. http://dx.doi.org/10.1089/jmf.2010.0143

HERRMANN, B. L.; SCHATZ, H.; PFEIFFER, A. Continuous blood glucose monitoring: the acute effect of acarbose on blood glucose variations. Medizinische Klinik, v. 93, n. 11, p. 651-5, 1998. http:// dx.doi.org/10.1007/BF03044876

HORII, A. et al. Primary structure of human pancreatic alphaamylase gene: its comparison with human salivary alpha-amylase gene. Gene, v. 60, p. 57-64, 1987. http://dx.doi.org/10.1016/03781119(87)90213-7

JOSSE, A. R. et al. Almonds and posprandial glycemia- a doseresponse study. Metabolism Clinical and Experimental, v. 56, p. 400-404, 2007. PMid:17292730. http://dx.doi.org/10.1016/j. metabol.2006.10.024

KÄHKÖNEN, M. P.; HOPIA, A. I.; HEINONEN, M. Berry phenolics and their antioxidant activity. Journal of Agricultural and Food Chemistry, v. 49, p. 4076-4082, 2001. PMid:11513713. http://dx.doi. org/10.1021/jf010152t

$\mathrm{KOH}, \mathrm{L}$. W. et al. Evaluation of different teas against starch digestibility by mammalian glycosidases. Journal of Agricultural and Food Chemistry, v. 58, p. 148-154, 2010. PMid:20050703. http://dx.doi. org/10.1021/jf903011g

KWON, Y. I.; VATTEM, D. A.; SHETTY, K. Clonal herbs of Laminaceae species against diabetes and hypertension. Asian Pacific Journal of Clinical Nutrition, v. 15, p. 424-432, 2006.

LAZARUS, S. A. et al. High-performance liquid chromatography/ mass spectrometry analysis of proanthocyanidins in foods and beverages. Journal of Agricultural and Food Chemistry, v. 47, p. 3693-3701, 1999. PMid:10552707. http://dx.doi.org/10.1021/ jf9813642

MANACH, C. et al. Polyphenols: food sources and bioavailability. American Journal of Clinical Nutrition, v. 79, p. 727-747, 2004. PMid:15113710.

McDOUGALL, G. J.; STEWART, D. The inhibitory effects of berry polyphenols on digestive enzymes. Biofactors, v. 23, n. 4, p. 189-195, 2005. PMid:16498205. http://dx.doi.org/10.1002/ biof. 5520230403

MILECH, A.; CHACRA, A. R.; KAYATH, M. J. Revisão da hiperglicemia pos-prandial e hipoglicemia no controle do diabetes mellitus: o papel da insulina lispro e suas pre-misturas nos picos e vales. Arquivos Brasileiros de Endocrinologia \& Metabologia, v. 45 , n. 5 , p. $423-432,2001$. http://dx.doi.org/10.1590/S000427302001000500004

NISHIKAWA, T. et al. Changes in diabetic retinal matrix protein mRNA levels in a common transgenic mouse strain. Current Eye Research, v. 21, p. 581-587, 2000. PMid:11035540. http://dx.doi. org/10.1076/0271-3683(200007)2111-ZFT581

PAJUELO, D. et al. Chronic dietary supplementation of proanthocyanidins corrects the mitochondrial dysfunction of brown adipose tissue caused by diet-induced obesity in Wistar rats. British Journal of Nutrition, v. 107, p. 170-178, 2011. PMid:21733324. http://dx.doi.org/10.1017/S0007114511002728

PEREIRA, L. L. S. Estudo comparativo entre faseolamina comercial e farinha de feijao como perspectiva ao tratamento da obesidade e do diabetes mellitus tipo 2. 2008. Dissertação (Mestrado em Agroquimica)-Universidade Federal de Lavras, Lavras, 2008.

PINTO, M. S.; LAJOLO, F. M.; GENOVESE, M. I. Bioactive compounds and quantification of total ellagic acid in strawberry (Fragaria $\times$ ananassa Duch). Food Chemistry, v. 107, p. 1629-1635, 2008. http:// dx.doi.org/10.1016/j.foodchem.2007.10.038

PINTO, M. S. et al. Evaluation of antihyperglycemia and antihypertension potential of native Peruvian fruits using in vitro models. Journal of Medicinal Food, v. 12, n. 2, p. 278-291, 2009. PMid:19459727. http://dx.doi.org/10.1089/jmf.2008.0113

PORTER, L. J.; HRSTICH, L. N.; CHAN, B. G. The conversion of procyanidins and prodelphinidins to cyanidin and delphinidin. Phytochemistry, v. 25, p. 223-230, 1986. http://dx.doi.org/10.1016/ S0031-9422(00)94533-3

PRIOR, R. L. et al. Multi-laboratory validation of a standard method for quantifying proanthocyanidins in cranberry powders. Journal of the Science of Food and Agriculture, v. 90, n. 9, p. 1473-1478, 2010. PMid:20549799. http://dx.doi.org/10.1002/jsfa.3966 
RANILLA, L. G. et al. Evaluation of indigenous grains from the Peruvian Andean region for antidiabetes and antihypertension potential using in vitro methods. Journal of Medicinal Food, v. 12, n. 4, p. 1-10, 2009. PMid:19735168. http://dx.doi.org/10.1089/ jmf.2008.0122

RANILLA, L. G. et al. Antidiabetes and antihypertension potential of commonly consumed carbohydrate sweeteners using in vitro models. Journal of Medicinal Food, v. 11, n. 2, p. 337-348, 2008. PMid:18598178. http://dx.doi.org/10.1089/jmf.2007.689

ROBBINS, R. J. et al. Method performance and multi-laboratory assessment of a normal phase high pressure liquid chromatographyfluorescence detection method for the quantitation of flavanols and procyanidins in cocoa and chocolate containing samples. Journal of Chromatography A, v. 1216, p. 4831-40, 2009. PMid:19426987. http://dx.doi.org/10.1016/j.chroma.2009.04.006

ROLO, A. P.; PALMEIRA, C. M. Diabetes and mitochondrial function: Role of hyperglycemia and oxidative stress. Toxicology and Applied Pharmacology, v. 212, p. 167-178, 2006. PMid:16490224. http:// dx.doi.org/10.1016/j.taap.2006.01.003

SINGLETON, V. L.; ORTHOFER, R.; LAMUELA-RAVENTOS, R. M. Analysis of total phenols and other oxidation substrates and antioxidants by means of Folin-Ciocalteu reagent. Methods in Enzymology, v. 299, p. 152-178, 1999. http://dx.doi.org/10.1016/ S0076-6879(99)99017-1

SONG, Y. et al. Associations of Dietary Flavonoids with Risk of Type 2 Diabetes, and Markers of Insulin Resistance and Systemic Inflammation in Women: A Prospective Study and Cross-Sectional Analysis. Journal of the American College of Nutrition, v. 24, n. 5, p. 376-384, 2005. PMid:16192263.

TOELLER, M. Alpha glucosidase inhibitors in diabetes: efficacy in NIDDM subjects. European Journal of Clinical Investigation, v. 24 , n. 3, p. 31-35, 1994. PMid:8001625. http://dx.doi. org/10.1111/j.1365-2362.1994.tb02253.x

TUNDIS, R.; LOIZZO, M. R.; MENICHINI, F. Natural products as alpha-amylase and alpha-glucosidase inhibitors and their hypoglycaemic potential in the treatment of diabetes: an update. Mini Reviews in Medicinal Chemistry, v. 10, p. 315-331, 2010. PMid:20470247. http://dx.doi.org/10.2174/138955710791331007

WALLACE, T. C.; GIUSTI, M. M. Evaluation of parameters that affect the 4-dimethylaminocinnamaldehyde assay for flavanols and proanthocyanidins. Journal of Food Science, v. 75, p. C61925, 2010. PMid:21535528. http://dx.doi.org/10.1111/j.17503841.2010.01734.x

WANG, Y. et al. Estimation of daily proanthocyanidin intake and major food sources in the U.S. diet. The Journal of Nutrition, v. 141, p. 447-452, 2011. PMid:21270367. http://dx.doi.org/10.3945/ jn. 110.133900

WORLD HEALTH ORGANIZATION - WHO. Definition, diagnosis and classification of diabetes mellitus and its complications. Geneva: WHO, 1999. Part I: diagnosis and classification of diabetes mellitus. Disponível em: <http://www.who.int/diabetes/ publications/en/>. Acesso em: 10 fev. 2009.

WILD, S. et al. Global prevalence of diabetes estimates for the year 2000 and projections 2030. Diabetes Care, v. 27, p. 1047-1053, 2004. PMid:15111519. http://dx.doi.org/10.2337/diacare.27.5.1047

ZAFRILLA, P.; FERRERES, F.; TOMÁS-BARBERÁN, F. A. Effect of processing and storage on the antioxidant ellagic acid derivatives and flavonoids of red raspberry (Rubus idaeus) jams. Journal of Agricultural and Food Chemistry, v. 49, p. 3651-3655, 2001. PMid:11513642. http://dx.doi.org/10.1021/jf010192x 